\title{
TOGA AND TOGATUS IN THE BOOKS OF THE MOZARABIC RITE。
}

WE know that though at Rome itself the use of the toga became unfashionable under the Empire and there was some difficulty in retaining it even at court and as the official dress of the civis Romanus, yet in the provinces its use spread further and further as a sign of civilization. In Cicero's day Cisalpine Gaul was apparently already called Togata, though Transalpine Gaul was dubbed Comata, because its inhabitants still wore unshorn locks (Phil. viii 27). But by the time of Agricola, one hundred years later, Tacitus tells us that even in Britain habitus nostri honor et frequens toga (Agric. chap. xxi).

It is not the object of this short paper to do more than give a few examples of the way in which the thoughts suggested by the use of this greatly and widely respected Roman dress were in the later days of the Empire adapted to religious purposes in one part of Western Christendom, viz. Spain.

The instances quoted of the participial adjective togatus are worth giving, though of less interest than the instances of the noun loga itself, which it is the writer's main object to bring forward.

No doubt both words started in the 'Mozarabic' books with the old Roman associations as describing the civilian garb (of white stuff) in the times of peace for the City and its colonies, and was then gradually applied to the heavenly garb of Christian martyrs and saints, togatus becoming an equivalent of candidatus.

Thus in the Breviarium Gothicum (Migne P.L. lxxxvi col. I I I2) we find urbis Romuleae iam toga candida. The meaning of toga we reserve for the moment, but obviously it is here closely connected with urbs Romulea, viz. Rome. And again (ibid. col. 1033) S. Julian, whose martyrdom is assigned to A. D. $30^{\circ}$, is called civis togate urbis Antiochie: this is, it would seem, quite an accurate epithet to use, as Antioch was made a colonia by Antoninus Pius ( $t_{1} 6 r$ ). With these two instances we may compare Prud. Perist. ii ro urbis togate (= Rome) insignibus and Cath. ii 39 miles, togatus, navita. Fr A. Lesley in his note on the passage from the Missal (col. 676) quoted further on says that Tarraco in Span was also called Togata ( $?$ as a colonia), but he does not quote his authority.

Three other instances of togatus occur in these books, and in all these its Christian application as we have suggested is obvious, viz. (1) Brev. Goth. col. I I 4 I chorus inde surgit | tendit in caelum niveus togate $\mid$ nobilitatis (= the band of noble martyrs in their snow-white robes); this is from Prudentius (Perist. iv 75): (2) Miss. Mozarab. (Migne P.L. $1 \mathrm{xxxv}$ col. 881) quem togatorum immensitas conlaudat 
sanctorum ( $=$ the vast host of white-robed saints): (3) Mozarab. Psalter ( $H B S$ vol. $\mathrm{xxx}$ fol. ${ }^{137}$ ) in a hymn de primttis ad vesperum we have candida veste togati in coro angeiico.

With regard to the noun $\operatorname{tog} a$, there is sufficient evidence that it was used in Spain (at all events in religious circles) as a collective noun, i. e. as an equivalent of coetus or chonus togatus, and it is this point which has been thought worthy of some special notice. Five instances can be adduced from the service books: (I) In the Missal (col. 676) one of the prayers addressed to S. Vincent the Spanish deacon-martyr $(+304)$ on his festival (Jan. 22) contains this clause: te huius caterve toga submissa fagitat mente. Three towns in Hispania Tarraconensis laid special claim to this saint, Huesca and Saragossa as rivals for being his birthplace and Valencia as the scene of his martyrdom. But it looks as if Fr Lesley (quoted above) was right in thinking that the phrase huius caterve toga ( $=$ this throng of toga-wearing worshippers) sought to include the whole province, and that the reference was rather to the old civilian garb of Rome than to the later Christian associations. Then there is (2) the passage allready quoted from the Breviary (col. I I I2): urbis Romuleae iam toga candida| septem pontificum destina (lit. 'prop' hence rule or authority) promicat. Here the reference is to the group of seven missionary bishops sent from Rome to evangelize Spain, of whom Torquatus was the leader; and toga and destina are in apposition, both being used in this curious collective way, $\operatorname{tog} a=\mathrm{a}$ togawearing group, destina $=$ a staff-bearing band (of rulers). (3) The Breviary (col. ro95) has a hymn in honour of S. Agatha, which contains these words : sacram effavit animam in caelos | toga cum sanctis, a condensed and quite ungrammatical clause to suit the metre: if the text is not corrupt, $\operatorname{tog} a$ (abl.) cum sanctis must be taken to stand for cum toga sanctorum: 'she breathed out her holy soul (and passed) into the heavens, (there to be) with the host of the white-robed saints.'

Lastly in the Liber Ordinum (edited by Dom Férotin, 1904) we have two nearly similar phrases where the plural is substituted for the singular (with no very obvious significance): (4) in an ordo votivus de energumeno (fol. $3^{69}$ ), angelorum togis adscitus, and (5) in a missa votiva de anniversario defuncti (fol. 448), electorum omnium togis adsatus. These last two phrases serve to indicate that the use of toga we have drawn attention to was peculiar to Spain, as the parallel phrases in other books (e.g. the Bobbio Missal and the Missale Gothicum, $H B S$ vols. lviii and lii) always employ other more ordinary words. And this view is corroborated by quotations given by Ducange s. $v$. from various Spanish charters (ed. Perez), where toga (monachorum or fratrum) occurs in the sense here discussed. It would seem also to have come into use at a later date than Prudentius, who only once 
gives toga a Christian reference, candidiore toga niveum pietatis amictum | sumere (c. Symm. i 547), and elsewhere employs the word in its older and more natural sense, e.g. sanciens | mundum Quirinali toge | servire et armis cedere (Perist. ii $4 \mathrm{r} 9$ ), a phrase reminiscent of Cicero's famous cedant arma togae.

\section{L. Feltoe.}

Since writing the above, another clear instance of this use of toga has come to my notice in the missa for SS. Simon and Jude (col. 889): solicita... convenire debet fidelium toga.

\section{JOSEPHUS ON JOHN THE BAPTIST.}

Is The Beginnings of Christianity vol. i p. $102 \mathrm{f}$ Dr Foakes Jackson and Dr Kirsopp Lake maintain that Josephus's version of the work of John Baptist has been generally misinterpreted by scholars, who have been misled by Whiston's translation of Antiquities xviii 5. 2. The

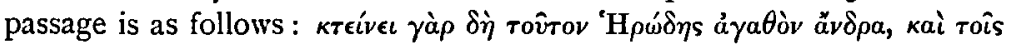

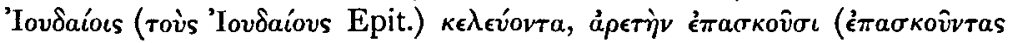

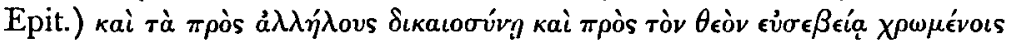

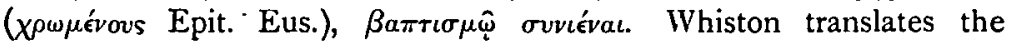
passage thus : 'For Herod slew him, who was a good man, and commanded the Jews to exercise virtue both as to justice toward one another and piety towards God, and so to come to baptism.' The editors of The Beginnings of Christianity criticize this rendering on the ground that it would require-the participles $\dot{\epsilon} \pi \sigma \kappa \kappa \hat{v} \sigma \iota \nu$ and $\chi \rho \omega \mu$ '́voเs to be in the accusative instead of the dative. '[Whiston's] explanation', they say, 'seems to have been adopted by the Epitome which has emended the datives into accusatives. This cannot be the true text, but there is perhaps a possibility that the text found in Eusebius Hist. Eccl. i I r. 5 is right which emends $\chi \rho \omega \mu$ évors into $\chi \rho \omega \mu$ évovs, but leaves '̇ $\pi \alpha \sigma \kappa o v \sigma \iota^{\prime}$ (p. 102 n. 2). The editớs themselves translate as follows: 'For Herod killed him, a good man, and one who commanded the Jews, training themselves in virtue and practising righteousness to one another and piety towards God, to come together for baptism.' This translation is literal, but ambiguous. It might still bear the same meaning as Whiston's more idiomatic version, which connects the participles with the infinitive ouviéval, or it may mean to construe the participles with rois 'Iovoaiors, thus giving a sense which would be more naturally represented in English by a relative clause-' John commanded 